\title{
Microbacterium azadirachtae sp. nov., a plant- growth-promoting actinobacterium isolated from the rhizoplane of neem seedlings
}

Correspondence Munusamy Madhaiyan mmadhaiyan@hotmail.com

\author{
Munusamy Madhaiyan, ${ }^{1}$ Selvaraj Poonguzhali, ${ }^{1}$ Jung-Sook Lee, ${ }^{2}$ \\ Keun-Chul Lee, ${ }^{2}$ Venkatakrishnan Sivaraj Saravanan ${ }^{3}$ \\ and Palani Santhanakrishnan ${ }^{1}$
}
${ }^{1}$ Department of Agricultural Microbiology, Tamilnadu Agricultural University, Coimbatore 641003 , Tamilnadu, India
${ }^{2}$ Korean Collection for Type Cultures (KCTC), Biological Resource Center (BRC), Korea Research Institute of Bioscience and Biotechnology (KRIBB), 111 Gwahangno, Yusong-gu, Daejeon 305- 806, Republic of Korea
${ }^{3}$ Department of Microbiology, Indira Gandhi College of Arts and Science, Pondicherry University, Kathirkamam 605 009, Pondicherry, India

\begin{abstract}
Microbacterium strain Al-S262 ${ }^{\top}$ was isolated from the rhizoplane of neem seedlings in the Botanical garden of Tamilnadu Agricultural University, Coimbatore, India, and subjected to phenotypic, chemotaxonomic and genetic characterization. Cells of this strain were Gram-stainpositive, motile, non-spore-forming, short rods and formed light-yellow-pigmented colonies on nutrient agar. Strain Al-S262 ${ }^{\top}$ contained MK-12 and MK-13 as the main respiratory quinones, anteiso- $\mathrm{C}_{15: 0}$, anteiso- $\mathrm{C}_{17: 0}$ and iso- $\mathrm{C}_{16: 0}$ as the predominant fatty acids, peptidoglycan-type B2 $\beta$ with glycolyl residues, and had a DNA G $+\mathrm{C}$ content of $69.5 \mathrm{~mol} \%$. A phylogenetic analysis based on 16S rRNA gene sequences showed 98.0-98.6\% pair-wise similarity with respect to close relatives in the genus Microbacterium. DNA-DNA hybridization experiments revealed a low level of DNA-DNA relatedness (less than 39\%) between strain Al-S262 ${ }^{\top}$ and its closest relatives. Data from DNA-DNA hybridization and phenotypic analyses supported the conclusion that strain $\mathrm{Al}-\mathrm{S} 262^{\top}$ represents a novel species in the genus Microbacterium, for which the name Microbacterium azadirachtae sp. nov. is proposed. The type strain is Al-S262 ${ }^{\top}\left(=\mathrm{JCM} 15681^{\top}\right.$ $=$ LMG $24772^{\top}=$ KCTC $19668^{\top}$ ).
\end{abstract}

Members of the genus Microbacterium can be isolated from a wide range of different environmental habitats from soil to insects to human clinical specimens to marine environments (Evtushenko \& Takeuchi, 2006; Park et al., 2008; Bakir et al., 2008; Takeuchi \& Hatano, 1998a, b; Lee et al., 2006; Shivaji et al., 2007; Collins \& Bradbury, 1992) and plants, having been reported from the phyllosphere of sugar beet and spring wheat, and as endophytes in sweet corn and cotton (Thompson et al., 1993; Legard et al., 1994; McInroy \& Kloepper, 1995). The genus Microbacterium, established by Orla-Jensen (1919) and emended

Abbreviations: ACC, 1-aminocyclopropane-1-carboxylate; IAA, indole-3acetic acid.

The GenBank/EMBL/DDBJ accession number for the 16S rRNA gene sequence of strain Al-S262 ${ }^{\top}$ is EU912487.

An extended phylogenetic tree, a scanning electron micrograph of cells of strain Al-S262 ${ }^{\top}$, and cellular fatty acid compositions of strain $\mathrm{Al}$ $\mathrm{S} 262^{\top}$ and type strains of related species are available with the online version of this paper. by Collins et al. (1983), comprises a diverse collection of Gram-positive, non-spore-forming, rod-shaped bacteria. More recently, the genus was further emended to include members of the genus Aureobacterium (Takeuchi \& Hatano, 1998b) and, at the time of writing, it included 61 recognized species (http://www.bacterio.cict.fr/m/ microbacterium.html\#aerolatum) isolated from different environmental sources. This paper describes a novel, plantgrowth-promoting species of the genus Microbacterium, Microbacterium azadirachtae sp. nov., isolated from the rhizoplane of neem seedlings.

Strain AI-S262 ${ }^{\mathrm{T}}$ was isolated from the rhizoplane of neem seedlings by the dilution-plating technique on R2A medium (Reasoner \& Geldreich, 1985; Difco) and was maintained as $50 \%$ glycerol stocks at $-80{ }^{\circ} \mathrm{C}$. Carbon source utilization pattern was studied by using Biolog GP2 Microplates following the manufacturer's instructions and acid production from various sugars was tested as described by Smith et al. (1952) and Madhaiyan et al. 
(2007b). Gram staining was performed by using the Gram staining kit (Difco), and bacterial suspensions were examined by phase-contrast microscopy for cell morphology and motility. The $\mathrm{pH}$ range for growth was determined on R2A agar. The growth temperature range $\left(4,10,20,25,30,37\right.$ and $\left.45{ }^{\circ} \mathrm{C}\right)$ and $\mathrm{NaCl}$ tolerance $[0,1,2$, $3,4,5$ and $10 \%(\mathrm{w} / \mathrm{v})]$ were tested on R2A medium. All tests were incubated at $30{ }^{\circ} \mathrm{C}$, unless otherwise indicated. Growth on nutrient agar, trypticase soy agar (Difco) and MacConkey agar was also evaluated at $30{ }^{\circ} \mathrm{C}$. Catalase activity was determined by assessing bubble production in $3 \%(\mathrm{v} / \mathrm{v}) \mathrm{H}_{2} \mathrm{O}_{2}$, and oxidase activity was determined with $1 \%(\mathrm{w} / \mathrm{v})$ tetramethyl- $\rho$-phenylenediamine, by using Difco BBL catalase and oxidase reagent droppers according to the manufacturer's instructions. Tests for the hydrolysis of starch, casein, lipids, CM-cellulose, gelatin, aesculin and pectin were performed and evaluated after 5 days (Atlas, 1993; Kouker \& Jaeger, 1987; Ten et al., 2004). Colony and cell morphology were determined by using phase-contrast microscopy. Sample preparation and other procedures for scanning electron microscope (SEM) observations were performed as described by Madhaiyan et al. (2007b) and the samples were visualized using a Hitachi S-2500C SEM with GEMINI column equipped with a field emission source. Isoprenoid quinones were extracted with chloroform/ methanol $(2: 1, \mathrm{v} / \mathrm{v})$ and purified by using TLC on Kieselgel $60 \quad \mathrm{~F}_{254}$ plates $(20 \times 20 \mathrm{~cm}, 0.5 \mathrm{~mm}$ thick; Merck) with petroleum ether/diethyl ether $(9: 1, \mathrm{v} / \mathrm{v})$ as the solvent. The quinones were identified by using reversed phase HPLC analysis, as described by Shin et al. (1996). Purified cell-wall preparations were obtained as described by Schleifer \& Kandler (1972). Amino acids and peptides in cell-wall hydrolysates were analysed by two-dimensional TLC on cellulose plates by using solvent systems described by Schleifer \& Kandler (1972). The cellular fatty acids were extracted from cultures grown in $\mathrm{R} 2 \mathrm{~A}$ medium at $28{ }^{\circ} \mathrm{C}$ for 4 to 5 days, derivatized to methyl esters, and analysed by a Gas Chromatograph (Hewlett Packard 6890) using the Microbial Identification System (MIDI; Microbial ID) software package, according to standard protocols (Sasser, 1990). Determination of minimal inhibitory concentrations of heavy metals and antibiotic resistance patterns was carried out as previously described (Madhaiyan et al., 2007a; Chanprame et al., 1996). The quantitative assay for estimation of indole-3-acetic acid (IAA) and plate assays for detecting the presence of siderophore production, phosphate solubilization, 1-aminocyclopropane-1-carboxylate (ACC) deaminase activity and sodium thiosulfate oxidation were carried out as previously described (Poonguzhali et al., 2006). A gnotobiotic assay using growth pouches was performed to measure the root elongation induced by ACC deaminase. Tomato and canola seeds were used for this root elongation assay, since they are representative of ethylene sensitive plants (Glick et al., 1994; Li et al., 2000; Penrose \& Glick, 2003; Ghosh et al., 2003; Madhaiyan et al., 2006, 2007b).
Cells of strain AI-S262 ${ }^{\mathrm{T}}$ were aerobic, motile, nonendospore forming, Gram-stain-positive short rods (0.3$0.4 \times 0.6-0.7 \mu \mathrm{m}$ ), occurring singly or in pairs on solid R2A medium and forming light-yellow, smooth and circular colonies with entire margins. Physiological, biochemical and chemotaxonomic characteristics of strain $\mathrm{AI}-\mathrm{S} 262^{\mathrm{T}}$ are given in the species description; those that serve to distinguish this strain from its closest phylogenetic neighbours are listed in Table 1 . The major fatty acids of strain $\mathrm{AI}-\mathrm{S} 262^{\mathrm{T}}$ were anteiso- $\mathrm{C}_{15: 0}$, anteiso- $\mathrm{C}_{17: 0 \text {, iso- }}$ $\mathrm{C}_{16: 0}$ and iso- $\mathrm{C}_{15: 0}$ (Supplementary Table S1, available in IJSEM Online). Strain AI-S262 ${ }^{\mathrm{T}}$ exhibited ACC deaminase activity, phosphate solubilization and sulfur oxidation when examined through plate assays but was negative for siderophore production. Strain AI-S262 ${ }^{\mathrm{T}}$ produced IAA and ACC deaminase activity at a concentration of $12.3 \mu \mathrm{g}$ $\mathrm{ml}^{-1}$ and a rate of $20.2 \mathrm{nmol} \alpha$-ketobutyrate $\min ^{-1}$ ( $\mathrm{mg}$ protein $)^{-1}$, respectively. From the gnotobiotic growth pouches assay, the root lengths of the AI-S262 ${ }^{\mathrm{T}}$-treated tomato (16.2\% increase over control) and canola (45.7\% increase over control) seeds were comparatively greater when compared with the uninoculated control (data not shown).

Chromosomal DNA was extracted according to the kit instructions (QIAamp DNA mini kit, Qiagen). The 16S rRNA gene was amplified using the universal primers 27F and 1492R as described by Madhaiyan et al. (2009) and the partial gene sequence was determined by the fluorescent dye terminator method using the $\mathrm{ABI}$ prism Big dye terminator cycle sequencing ready reaction kit (version 3.1); products were run on an ABI3730XL capillary DNA sequencer (ABI Prism 310 Genetic Analyzer). The resultant 16S rRNA gene sequence was compared with representative organisms from the same and related genera from GenBank and was aligned by using CLUSTAL w (Thompson et al., 1994) multiple alignments. Phylogenetic trees were reconstructed by the neighbour-joining (Saitou \& Nei, 1987) and maximumparsimony (Fitch, 1971) methods, using the MEGA 4.1 program (Tamura et al., 2007), and bootstrap values were based on 1000 replications (Felsenstein, 1985). DNA-DNA hybridizations were carried out on nitrocellulose membrane filters according to the method of Seldin \& Dubnau (1985). The DIG-High prime system and DIG luminescent detection kit (Roche Diagnostics) were used for labelling the probe DNA and visualization. Hybridization temperatures were 60 and $65{ }^{\circ} \mathrm{C}$ and the DNA-DNA relatedness was quantified by using a densitometer (Bio-Rad). The $\mathrm{G}+\mathrm{C}$ content of the genomic DNA was determined by HPLC analysis using a reversed-phase column (Supelcosil LC$18 \mathrm{~S}$, Supelco) of individual nucleosides as described by Mesbah et al. (1989).

Preliminary sequence comparisons with 16S rRNA gene sequences held in GenBank indicated that the isolate was closely related to the genus Microbacterium. In the phylogenetic tree (Fig. 1; an extended version of this tree is available as Supplementary Fig. S1), strain AI-S262 ${ }^{\mathrm{T}}$ clustered within the genus Microbacterium of the class 
Table 1. Phenotypic characteristics that differentiate strain $\mathrm{Al}-\mathrm{S} 262^{\top}$ from related species of the genus Microbacterium

Strains: 1, AI-S262 ${ }^{\mathrm{T}}$; 2, Microbacterium resistens DMMZ $1710^{\mathrm{T}} ; 3$, M. testaceum DSM $20166^{\mathrm{T}}$; 4, M. aerolatum V-73 ${ }^{\mathrm{T}} ; 5$, M. esteraromaticum DSM $8609^{\mathrm{T}} ; 6$, M. arabinogalactanolyticum DSM $8611^{\mathrm{T}} ; 7$, M. foliorum DSM $12966^{\mathrm{T}} ; 8$, M. phyllosphaerae DSM $13468^{\mathrm{T}} ; 9$, M. paraoxydans CF36 ${ }^{\mathrm{T}}$; 10, M. . natoriense TNJL143-2 ${ }^{\mathrm{T}}$. The cell wall contains ornithine as diamino acid and the peptidoglycan type is B2 $\beta$ for all strains except M. resistens DMMZ $1710^{\mathrm{T}}(\mathrm{B} 2 \alpha)$. +, Positive; -, negative; w, weakly positive; Y, yellow; YO, yellow-orange; Yw, yellow-white; LY, light-yellow. All data were obtained in this study.

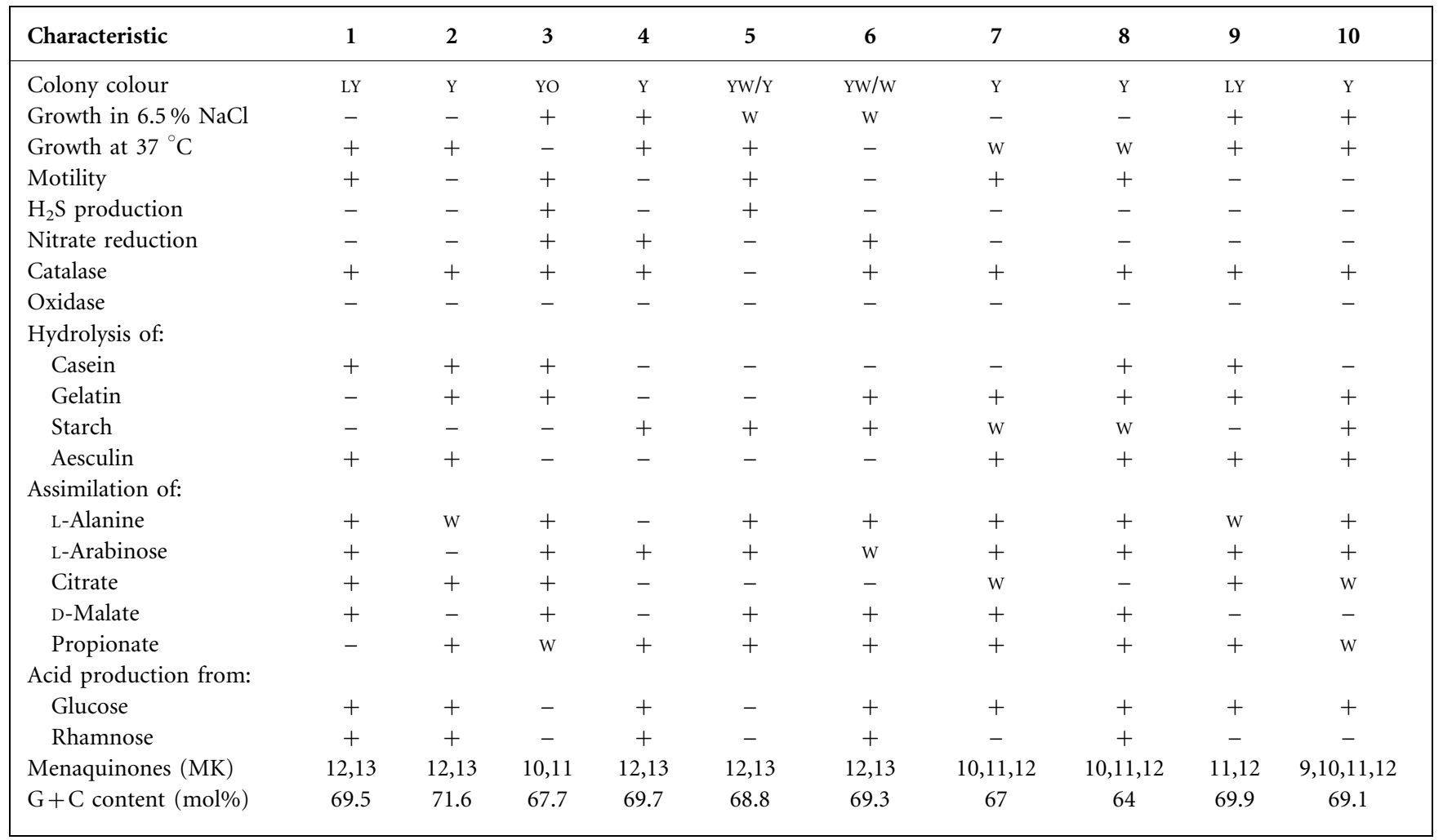

Actinobacteria. Strain AI-S262 ${ }^{\mathrm{T}}$ showed the highest $16 \mathrm{~S}$ rRNA gene sequence similarity to the type strains of Microbacterium aerolatum (98.6\% pairwise similarity),
M. resistens (98.5\%), M. testaceum (98.3\%), M. foliorum (98.3\%), M. phyllosphaerae (98.3\%), M. natoriense (98.3\%), M. paraoxydans (98.2\%), M. esteraromaticum

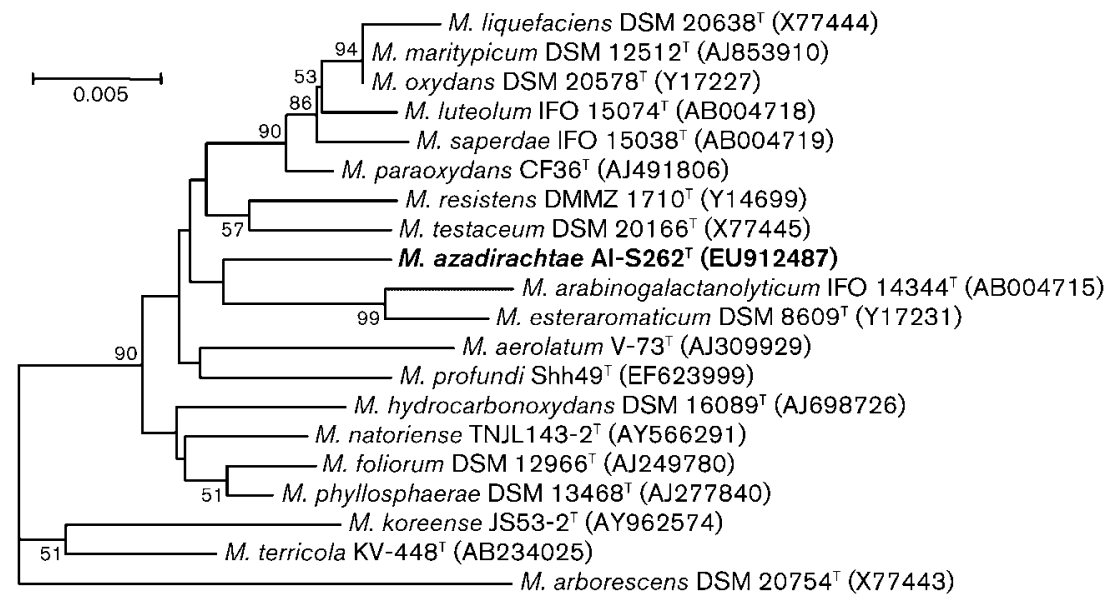

Fig. 1. Phylogenetic tree based on $16 \mathrm{~S}$ rRNA gene sequence comparison showing the position of strain $\mathrm{Al}-\mathrm{S} 262^{\top}$ and other related species of the genus Microbacterium. Numbers at nodes indicate levels of bootstrap support based on a neighbourjoining analysis of 1000 resampled datasets. Bootstrap values below $50 \%$ are not shown. Bar, 0.005 substitutions per site. 
(98.2\%) and M. arabinogalactanolyticum (98.0\%). Strain AI-S262 ${ }^{\mathrm{T}}$ showed a low level of DNA-DNA relatedness, that ranged between 11 and $39 \%$, with its closest relatives M. aerolatum $\mathrm{V}-73^{\mathrm{T}}(39 \pm 2.9 \%)$, M. resistens DMMZ $1710^{\mathrm{T}}(34 \pm 2.1 \%)$, M. foliorum DSM $12966^{\mathrm{T}}(32 \pm 2.3 \%)$, M. paraoxydans $\mathrm{CF} 36^{\mathrm{T}}(31 \pm 2.0 \%)$, M. esteraromaticum DSM $8609^{\mathrm{T}}(28 \pm 1.4 \%), \quad M$. testaceum DSM $20166^{\mathrm{T}}$ $(24 \pm 1.6 \%)$, M. phyllosphaerae DSM $13468^{\mathrm{T}}(17 \pm 1.0 \%)$, M. arabinogalactanolyticum DSM $8611^{\mathrm{T}}(16 \pm 1.2 \%)$ and M. natoriense TNJL143-2 ${ }^{\mathrm{T}}(11 \pm 0.8 \%)$. The DNA-DNA hybridization data revealed that strain AI-S262 ${ }^{\mathrm{T}}$ did not belong to any of the previously described species of the genus Microbacterium, when the recommendation of a threshold value of $70 \%$ DNA-DNA similarity for species definition is considered (Wayne et al., 1987). The DNA $\mathrm{G}+\mathrm{C}$ content of strain AI-S262 ${ }^{\mathrm{T}}$ was $69.5 \mathrm{~mol} \%$, which falls within the range described for the genus Microbacterium (Orla-Jensen, 1919; Skerman et al., 1980). On the basis of the results described, strain AI-S262 ${ }^{\mathrm{T}}$ represents a novel species of the genus Microbacterium, for which the name Microbacterium azadirachtae sp. nov. is proposed.

\section{Description of Microbacterium azadirachtae sp. nov.}

Microbacterium azadirachtae (a.za.di.rach'ta.e. N.L. n. azadirachta a botanical genus name; N.L. gen. n. azadirachtae of Azadirachta, isolated from Azadirachta indica).

Cells are Gram-positive, strictly aerobic, motile and short rods, approximately $0.3-0.4 \mu \mathrm{m}$ wide and $0.6-0.7 \mu \mathrm{m}$ long, occurring singly or in pairs (see Supplementary Fig S2). Spore formation is not observed. Colonies are 1-2 $\mathrm{mm}$ in diameter, smooth, circular and light-yellow after $48 \mathrm{~h}$ at $28{ }^{\circ} \mathrm{C}$ on $\mathrm{R} 2 \mathrm{~A}$ agar. $\mathrm{NaCl}$ concentration for growth is 0 $5.5 \%(\mathrm{w} / \mathrm{v})$, with an optimum at $0-1 \%$. pH and temperature ranges for growth are $\mathrm{pH} 5.0-10.0$ and 10 $37{ }^{\circ} \mathrm{C}$ (optimum at $\mathrm{pH} 7.0-8.0$ and $28{ }^{\circ} \mathrm{C}$ ). Catalasepositive, oxidase-negative. Nitrate is not reduced to nitrite. Aesculin, casein and tributyrin are hydrolysed. Starch, gelatin and urea are not hydrolysed. No growth on MacConkey agar. Tolerates up to $1 \mathrm{mM} \mathrm{NiCl} 2$ and $<0.5 \mathrm{mM} \mathrm{CdCl}_{2}$ in plate assays. The type strain is highly resistant to bacitracin, cephalosporin, nalidixic acid and polymyxin $\mathrm{B}$ (all at $500 \mu \mathrm{g} \mathrm{ml}^{-1}$ ), but sensitive to ampicillin $\left(25 \mu \mathrm{g} \mathrm{ml}{ }^{-1}\right)$, carbenicillin $\left(300 \mu \mathrm{g} \mathrm{ml}^{-1}\right)$, cefotaxime $\left(25 \mu \mathrm{g} \mathrm{ml}{ }^{-1}\right)$, chloramphenicol $(100 \mu \mathrm{g}$ $\left.\mathrm{ml}^{-1}\right)$, doxycycline $\left(50 \mu \mathrm{g} \mathrm{ml}^{-1}\right)$, erythromycin $(25 \mu \mathrm{g}$ $\left.\mathrm{ml}^{-1}\right)$, gentamicin $\left(50 \mu \mathrm{g} \mathrm{ml}^{-1}\right)$, kanamycin $\left(25 \mu \mathrm{g} \mathrm{ml}^{-1}\right)$, novobiocin $\left(25 \mu \mathrm{g} \mathrm{ml}^{-1}\right)$, penicillin $\mathrm{G}\left(25 \mu \mathrm{g} \mathrm{ml} \mathrm{m}^{-1}\right)$, rifampicin $\left(100 \mu \mathrm{g} \mathrm{ml}^{-1}\right)$, spectinomycin $\left(300 \mu \mathrm{g} \mathrm{ml}^{-1}\right)$, tetracycline $\left(500 \mu \mathrm{g} \mathrm{ml}^{-1}\right)$, trimethoprim $\left(100 \mu \mathrm{g} \mathrm{ml}^{-1}\right)$ and vancomycin $\left(25 \mu \mathrm{g} \mathrm{m}^{-1}\right)$. The following carbon substrates are assimilated for growth (Biolog GP2 Microplates): $\beta$-cyclodextrin, dextrin, Tween 40, Tween $80, N$-acetyl-D-galactosamine, $N$-acetyl- $\beta$-D-mannosamine, amygdalin, L-arabinose, D-arabitol, arbutin, cellobiose, Dfructose, L-fucose, D-galactose, gentiobiose, D-gluconic acid, $\alpha$-D-glucose, myo-inositol, maltose, maltotriose, Dmannitol, D-mannose, melezitose, methyl $\beta$-D-glucoside, palatinose, D-psicose, L-rhamnose, salicin, D-sorbitol, sucrose, D-tagatose, trehalose, turanose, acetic acid, $\beta$ hydroxybutyric acid, $\gamma$-hydroxybutyric acid, $\rho$-hydroxy phenylacetic acid, $\alpha$-ketobutyric acid, D-lactic acid methyl ester, L-lactic acid, D-malic acid, L-malic acid, pyruvic acid methyl ester, pyruvic acid, succinamic acid, succinic acid, $\mathrm{N}$-acetyl-L-glutamic acid, L-alaninamide, D-alanine, Lalanine, L-alanyl glycine, L-asparagine, L-glutamic acid, glycyl L-glutamic acid, L-serine, putrescine, glycerol, adenosine, 2 '-deoxyadenosine, inosine, thymidine, uridine and adenosine- 5 '-monophosphate. Negative for $\alpha$-cyclodextrin, glycogen, inulin, mannan, D-galacturonic acid, lactose, lactulose, melibiose, methyl $\alpha$-D-galactoside, methyl $\beta$-D-galactoside, 3-methyl-D-glucose, methyl $\alpha$-Dglucoside, methyl $\alpha$-D-mannoside, raffinose, D-ribose, sedoheptulosan, stachyose, xylitol, D-xylose, $\alpha$-hydroxybutyric acid, $\alpha$-ketovaleric acid, lactamide, succinic acid monomethyl ester, propionic acid, L-pyroglutamic acid, 2,3-butanediol, thymidine-5' -monophosphate, uridine-5' monophosphate, D-fructose 6-phosphate, $\alpha$-D-glucose 1phosphate, D-glucose 6-phosphate and DL- $\alpha$-glycerol phosphate. Positive for plant-growth-promoting traits including IAA production, P-solubilization, ACC deaminase activity and sulfur oxidation in plate assays, but negative for siderophore production. The predominant menaquinones are MK-12 and MK-13. The cell wall contains ornithine as diamino acid, the peptidoglycan type is $\mathrm{B} 2 \beta$ with glycolyl residues. The major cellular fatty acids are anteiso- $\mathrm{C}_{15: 0}$, anteiso- $\mathrm{C}_{17: 0}$, iso- $\mathrm{C}_{16: 0}$ and iso- $\mathrm{C}_{15: 0}$. The $\mathrm{G}+\mathrm{C}$ content of the genomic DNA of the type strain is $69.5 \mathrm{~mol} \%$.

The type strain, AI-S262 ${ }^{\mathrm{T}}\left(=\mathrm{JCM} 15681^{\mathrm{T}}=\mathrm{LMG} 24772^{\mathrm{T}}\right.$ $=$ KCTC $19668^{\mathrm{T}}$ ), was isolated from the rhizoplane of neem seedlings at Tamilnadu Agricultural University (TNAU), Coimbatore, Tamilnadu, India.

\section{Acknowledgements}

We wish to thank Yoshimasa Kosako, Japan Collection of Microorganisms, RIKEN, Wako, Japan and ir. Claudine Vereecke, BCCM/LMG Bacteria Collection, Belgium for their valuable advice. We also thank Professor Jean P. Euzéby for his valuable advice on nomenclature.

\section{References}

Atlas, R. M. (1993). Handbook of Microbiological Media, pp. 196, 843. Edited by L. C. Parks. Boca Raton, FL: CRC Press.

Bakir, M. A., Kudo, T. \& Benno, Y. (2008). Microbacterium hatanonis sp. nov., isolated as a contaminant of hairspray. Int J Syst Evol Microbiol 58, 654-658.

Chanprame, S., Todd, J. J. \& Widholm, J. M. (1996). Prevention of pink-pigmented methylotrophic bacteria (Methylobacterium mesophilicum) contamination of plant tissue cultures. Plant Cell Rep 16, 222225. 
Collins, M. D. \& Bradbury, J. F. (1992). The genera Agromyces, Aureobacterium, Clavibacter, Curtobacterium, and Microbacterium. In The Prokaryotes, pp. 1355-1368. Edited by A. Balows, H. G. Trüper, M. Dworkin, W. Harder \& K.-H. Schleifer. Berlin: Springer.

Collins, M. D., Jones, D. \& Kroppenstedt, R. M. (1983). Reclassification of Brevibacterium imperiale (Steinhaus) and 'Corynebacterium laevaniformans' (Dias and Bhat) in a redefined genus Microbacterium (Orla-Jensen), as Microbacterium imperiale comb. nov. and Microbacterium laevaniformans nom. rev., comb. nov. Syst Appl Microbiol 4, 65-78.

Evtushenko, L. I. \& Takeuchi, M. (2006). The family Microbacteriaceae. In The Prokaryotes: a Handbook on the Biology of Bacteria, 3rd edn, vol. 3, pp. 1020-1098. Edited by M. Dworkin, S. Falkow, E. Rosenberg, K. H. Schleifer \& E. Stackebrandt. New York: Springer.

Felsenstein, J. (1985). Confidence limits on phylogenies: an approach using the bootstrap. Evolution 39, 783-791.

Fitch, W. M. (1971). Toward defining the course of evolution: minimum change for a specific tree topology. Syst Zool 20, 406-416.

Ghosh, S., Penterman, J. N., Little, R. D., Chavez, R. \& Glick, B. R. (2003). Three newly isolated plant growth-promoting bacilli facilitate the seedling growth of canola, Brassica campestris. Plant Physiol Biochem 41, 277-281.

Glick, B. R., Jacobson, C. B., Schwarze, M. M. K. \& Pasternak, J. J. (1994). 1-Aminocyclopropane-1-carboxylic acid deaminase mutants of the plant growth promoting rhizobacterium Pseudomonas putida GR12-2 do not stimulate canola root elongation. Can J Microbiol 40, 911-915.

Kouker, G. \& Jaeger, K.-E. (1987). Specific and sensitive plate assay for bacterial lipase. Appl Environ Microbiol 53, 211-213.

Lee, J.-S., Lee, K. C. \& Park, Y.-H. (2006). Microbacterium koreense sp. nov., from sea water in the South Sea of Korea. Int J Syst Evol Microbiol 56, 423-427.

Legard, D. E., McQuilken, M. P., Whipps, J. M., Fenlon, J. S., Fermor, T. R., Thompson, I. P., Bailey, M. J. \& Lynch, J. M. (1994). Studies of seasonal changes in the microbial populations on the phyllosphere of spring wheat as a prelude to the release of a genetically modified microorganism. Agric Ecosyst Environ 50, 87-101.

Li, J., Ovakim, D. H., Charles, T. C. \& Glick, B. R. (2000). An ACC deaminase minus mutant of Enterobacter cloacae UW4 no longer promotes root elongation. Curr Microbiol 41, 101-105.

Madhaiyan, M., Poonguzhali, S., Ryu, J. \& Sa, T. (2006). Regulation of ethylene levels in canola (Brassica campestris) by 1-aminocyclopropane-1-carboxylate deaminase-containing Methylobacterium fujisawaense. Planta 224, 268-278.

Madhaiyan, M., Poonguzhali, S. \& Sa, T. (2007a). Metal tolerating methylotrophic bacteria reduces nickel and cadmium toxicity and promotes plant growth of tomato (Lycopersicon esculentum L.). Chemosphere 69, 220-228.

Madhaiyan, M., Kim, B.-Y., Poonguzhali, S., Kwon, S.-W., Song, M.-H., Ryu, J.-H., Go, S.-J., Koo, B.-S. \& Sa, T.-M. (2007b). Methylobacterium oryzae sp. nov., an aerobic, pink-pigmented, facultatively methylotrophic, 1-aminocyclopropane-1-carboxylate deaminase-producing bacterium isolated from rice. Int J Syst Evol Microbiol 57, 326-331.

Madhaiyan, M., Poonguzhali, S., Kwon, S.-W. \& Sa, T.-M. (2009). Methylobacterium phyllosphaerae sp. nov., a pink-pigmented facultatively methylotrophic bacterium from rice. Int J Syst Evol Microbiol 59, 22-27.

Mclnroy, J. A. \& Kloepper, J. W. (1995). Survey of indigenous bacterial endophytes from cotton and sweet corn. Plant Soil 173, 337-342.
Mesbah, M., Premachandran, U. \& Whitman, W. B. (1989). Precise measurement of the $\mathrm{G}+\mathrm{C}$ content of deoxyribonucleic acid by highperformance liquid chromatography. Int J Syst Bacteriol 39, 159-167.

Orla-Jensen, S. (1919). The Lactic Acid Bacteria. Copenhagen: Høst and Son.

Park, M.-J., Kim, M. K., Kim, H.-B., Im, W.-T., Yi, T.-H., Soung, N.-K. \& Yang, D.-C. (2008). Microbacterium ginsengisoli sp. nov., a $\beta$-glucosidase producing bacterium isolated from soil of a ginseng field. Int J Syst Evol Microbiol 58, 429-433.

Penrose, D. M. \& Glick, B. R. (2003). Methods for isolating and characterizing ACC deaminase-containing plant growth-promoting rhizobacteria. Physiol Plant 118, 10-15.

Poonguzhali, S., Madhaiyan, M. \& Sa, T. M. (2006). Cultivationdependent characterization of rhizobacterial communities from field grown Chinese cabbage Brassica campestris ssp pekinensis and screening of traits for potential plant growth promotion. Plant Soil 286, 167-180.

Reasoner, D. J. \& Geldreich, E. E. (1985). A new medium for the enumeration and subculture of bacteria from potable water. Appl Environ Microbiol 49, 1-7.

Saitou, N. \& Nei, M. (1987). The neighbor-joining method: a new method for reconstructing phylogenetic trees. Mol Biol Evol 4, 406-425.

Sasser, M. (1990). Identification of bacteria through fatty acid analysis. In Methods in Phytobacteriology, pp. 199-204. Edited by Z. Klement, K. Rudolph \& D. C. Sands. Budapest: Akademiai Kiado.

Schleifer, K. H. \& Kandler, O. (1972). Peptidoglycan types of bacterial cell walls and their taxonomic implications. Bacteriol Rev 36, 407-477.

Seldin, L. \& Dubnau, D. (1985). Deoxyribonucleic acid homology among Bacillus polymyxa, Bacillus macerans, Bacillus azotofixans, and other nitrogen-fixing Bacillus strains. Int J Syst Bacteriol 35, 151-154.

Shin, Y. K., Lee, J.-S., Chun, C. O., Kim, H.-J. \& Park, Y.-H. (1996). Isoprenoid quinone profiles of Leclercia adecarboxylata KCTC $1036^{\mathrm{T}}$. J Microbiol Biotechnol 6, 68-69.

Shivaji, S., Bhadra, B., Rao, R. S., Chaturvedi, P., Pindi, P. K. \& Raghukumar, C. (2007). Microbacterium indicum sp. nov., isolated from a deep-sea sediment sample from the Chagos Trench, Indian Ocean. Int J Syst Evol Microbiol 57, 1819-1822.

Skerman, V. B. D., McGowan, V. \& Sneath, P. H. A. (editors) (1980). Approved lists of bacterial names. Int J Syst Bacteriol 30, 225-420.

Smith, N. R., Gordon, R. E. \& Clark, F. E. (1952). Aerobic spore forming bacteria. Agricultural Monograph no. 16. Washington, DC: US Department of Agriculture.

Takeuchi, M. \& Hatano, K. (1998a). Union of the genera Microbacterium Orla-Jensen and Aureobacterium Collins et al. in a redefined genus Microbacterium. Int J Syst Bacteriol 48, 739-747.

Takeuchi, M. \& Hatano, K. (1998b). Proposal of six new species in the genus Microbacterium and transfer of Flavobacterium marinotypicum ZoBell and Upham to the genus Microbacterium as Microbacterium maritypicum comb. nov. Int J Syst Bacteriol 48, 973-982.

Tamura, K., Dudley, J., Nei, M. \& Kumar, S. (2007). MEGA4: molecular evolutionary genetics analysis (MEGA) software version 4.0. Mol Biol Evol 24, 1596-1599.

Ten, L. N., Im, W.-T., Kim, M.-K., Kang, M. S. \& Lee, S.-T. (2004). Development of a plate technique for screening of polysaccharidedegrading microorganisms by using a mixture of insoluble chromogenic substrates. J Microbiol Methods 56, 375-382.

Thompson, I. P., Bailey, M. J., Fenlon, J. S., Fermor, T. R., Lilley, A. K., Lynch, J. M., McCormack, P. J., McQuilken, M. P., Purdy, K. J. \& other authors (1993). Quantitative and qualitative seasonal changes in the microbial community from the phyllosphere of sugar beet (Beta vulgaris). Plant Soil 150, 177-191. 
Thompson, J. D., Higgins, D. G. \& Gibson, T. J. (1994). CLUSTAL W: improving the sensitivity of progressive multiple sequence alignment through sequence weighting, position-specific gap penalties and weight matrix choice. Nucleic Acids Res 22, 4673 4680 .
Wayne, L. G., Brenner, D. J., Colwell, R. R., Grimont, P. A. D., Kandler, O., Krichevsky, M. I., Moore, L. H., Moore, W. E. C., Murray, R. G. E. \& other authors (1987). International Committee on Systematic Bacteriology. Report of the ad hoc committee on reconciliation of approaches to bacterial systematics. Int J Syst Bacteriol 37, 463-464. 